\title{
Research on the Teaching Practice of Japanese Bookkeeping in Japanese Majors in Colleges and Universities
}

\author{
Yingying $\mathrm{Fu}^{1, *}$ \\ ${ }^{1}$ Department of Japanese, Dalian Neusoft University of Information, Dalian, Liaoning, China \\ *Corresponding author. Email: fuyingying@neusoft.edu.cn
}

\begin{abstract}
In this paper, "Japanese bookkeeping teaching" is taken as the research object. Based on CDIO concept and the teaching experience of Japanese bookkeeping and combined with the teaching characteristics of interdisciplinary courses, the author explores the teaching mode of Japanese bookkeeping talents training from the aspects of teaching content, teaching methods and specific teaching implementation.
\end{abstract}

Keywords: Japanese Bookkeeping, Teaching mode, Practical research.

\section{INTRODUCTION}

"簿记" is translated from English bookkeeping (a kind of bookkeeping methods). It mainly refers to the management of assets, liabilities, net assets increase and decrease, and the record of income and expenses in a certain period. In Japan, bookkeeping is an essential knowledge in business activities, which should be mastered not only by the accountants, but also by the managers and staff of the business departments of the company.

As the BPO business in the Chinese market continues to be popular, in recent years, the BPO business with Japan has been upgraded from the previous low-end BPO business, which mainly focused on Japanese input, to the middle and highend financial BPO business. Therefore, the demand for talents who have certain financial professional skills and good Japanese language ability to engage in mid-to-high-end financial BPO business has increased significantly. Since 2013, the Japanese Bookkeeping Qualification Examination has been introduced into China. In China, people can participate in the bookkeeping qualification certification synchronized with Japan. It can be seen that Japan attaches great importance to the bookkeeping qualification certification and Japanese enterprises in China need bookkeeping talents. It is particularly important for training talents who have abilities of "Japanese + bookkeeping". According to the survey, more than 30 Japanese majors in colleges and universities and Japanese education institutions in China have offered courses related to Japanese bookkeeping, and many Japanese majors in colleges and universities have also consciously offered such courses and trained Japanese bookkeeping teachers through training institutions.

This thesis mainly refers to related researches on accounting-related teaching methods in China and Japan and the teaching characteristics of interprofessional courses. Before the 1950 s, there was a saying that beginners in accounting usually learn bookkeeping first and then learn accounting. Bookkeeping is the basic technical work of accounting, so the teaching method of accounting for accounting treatment can be used as a reference. In terms of teaching design, it is necessary to fully consider the differences between basic Japanese teaching and Japanese bookkeeping teaching, recognize the teaching characteristics of interdisciplinary courses, understand the differences in thinking mode, knowledge structure and interests of students of liberal arts and science, and effectively bring into play and guide the characteristics of students who participate in interdisciplinary course.

\section{TEACHING PRACTICE BACKGROUND OF JAPANESE BOOKKEEPING COURSE}

Since 2012, in order to meet the enterprise's demand for BPO talents in Japanese financial business, Japanese Department of Dalian Neusoft University of Information has set up the BPO 
initiative customization project in SOVO (the innovation and practice base) for 10 consecutive periods, so as to cultivate "Japanese bookkeeping" talents. With the maturity of this mode, the project was incorporated into the talent training program in 2016 and became a limited course for Japanese majors, which was set up in the first semester of the third year. There are about 60 students taking this course every year. The textbook used in this course is "basic Japanese bookkeeping course" published by FLTRP (Foreign Language Teaching and Research Press).

Combined with the teaching experience of Japanese bookkeeping course in Japanese Department of Dalian Neusoft University of Information, this paper explores the teaching mode of Japanese bookkeeping course.

\section{RESEARCH ON THE TEACHING MODE OF JAPANESE BOOKKEEPING COURSE}

\subsection{Teaching Objectives}

Japanese bookkeeping talents are mainly trained through the "Japanese bookkeeping course". Based on the design of training objectives in CDIO syllabus of Japanese bookkeeping course, Japanese bookkeeping talents are required to understand the basic process of Japanese bookkeeping in business activities, master the basic concepts of Japanese bookkeeping, be able to understand Japanese financial statements, master accounting standards, master how to keep accounts in business transactions, how to fill in account books, and learn daily bookkeeping and annual bookkeeping methods. And then, they can obtain the third level of bookkeeping qualification certification, be engaged in works related to financial BPO business, have good foundation for the in-depth study of Japanese bookkeeping, master the basic theory and professional terminology, and be able to adapt to work directly. The exploration of teaching mode of Japanese bookkeeping talent training will be based on this. Also, it is suggested to design specific teaching content.

\subsection{Teaching Contents}

Teaching content is dynamically generated materials and information that interact with teachers and students in the teaching process and serve the achievement of teaching objectives. As a carrier for teaching content, teaching materials are one of the basic elements of teaching, the basis for teachers to teach, and the basic tool for students to acquire knowledge. Currently, the teaching materials used by colleges and universities that set up Japanese bookkeeping courses include "Basics of Japanese Bookkeeping" published by Dalian University of Technology Press, "General Bookkeeping Ability Verification" published by Shanghai Jiaotong University Press, and "Basic Japanese Bookkeeping Course" published by Foreign Language Teaching and Research Press", "Bookkeeping Course (Level 3)" published by Northeast Normal University Press. Among them, the "Basic Japanese Bookkeeping Course" published by Foreign Language Teaching and Research Press is written in Japanese, with detailed explanations and rich examples. Since its publication in April 2016, many universities have begun to use it. In line with the teaching materials used, it is generally to set 30-36 class hours for Japanese bookkeeping courses.

The teaching material used in "Japanese Bookkeeping" course is the "Basic Japanese Bookkeeping Course" published by Foreign Language Teaching and Research Press. When designing teaching content, teachers are required to carefully analyze teaching objectives, teaching objects, teaching materials, etc., rationally select and organize teaching contents, and reasonably express teaching content. Through scientific processing and reasonable organization of the contents of the textbook, the specific teaching contents of this course are summarized in "Table 1" below.

Table 1. Teaching content of Japanese bookkeeping course

\begin{tabular}{|c|l|l|}
\hline Unit & \multicolumn{1}{|c|}{ Name } & \multicolumn{1}{c|}{ Knowledge Point } \\
\hline Unit 1 & Daily bookkeeping basics & Basic concepts, bookkeeping principles, accounting entries, registration book \\
\hline Unit 2 & Purchases and sales & $\begin{array}{l}\text { The application of bookkeeping in the purchases and sales of commodities } \\
\text { trichotomy: record methods used when having credit, return and freight, record } \\
\text { methods on dealing with general ledger, accounts receivable and payable, } \\
\text { commodity in warehouse. }\end{array}$ \\
\hline Unit 3 & Cash & Bookkeeping of cash, bank deposits and petty cash \\
\hline Unit 4 & Bill & Bookkeeping of promissory note, money order, endorsement transfer and discount \\
\hline Unit 5 & Other transaction processing & $\begin{array}{l}\text { There are seven portfolio accounting subjects: loans, loans borrowed by promissory } \\
\text { notes, accounts not collected and paid, accounts received and paid in advance, } \\
\text { withholding expenses, other receivables and payables, and commodity bonds }\end{array}$ \\
\hline
\end{tabular}




\begin{tabular}{|c|c|c|}
\hline Unit & Name & Knowledge Point \\
\hline Unit 6 & Negotiable securities, fixed assets & The buying and selling of securities, the purchase and depreciation of fixed assets \\
\hline Unit 7 & Trial balance & Fabrication and calculation method of trial balance \\
\hline Unit 8 & Net asset, pay taxes & Increase or decrease in net assets, accounting treatment of tax payment \\
\hline Unit 9 & $\begin{array}{l}\text { Main accounting books, auxiliary } \\
\text { accounting books }\end{array}$ & The recording of primary and subsidiary accounting books \\
\hline Unit 10 & Certificate & use of certificate \\
\hline Unit 11 & Closing adjustment & $\begin{array}{l}\text { The basic concept and related processing of final account arrangement, the } \\
\text { production and calculation method of actuarial tables, the basic contents and filling } \\
\text { items of financial statements }\end{array}$ \\
\hline
\end{tabular}

\subsection{Teaching Methods}

The teaching method is the unity of the teacher's teaching method and the student's learning method. The teaching method must be based on the learning method of the teaching object, otherwise it will not be able to effectively complete the teaching content and teaching objectives due to the lack of pertinence and feasibility.

For students majoring in Japanese, they learn interdisciplinary Japanese bookkeeping course. Teachers should pay attention to stimulate students' interest in learning, guide students to think actively, comprehensively and systematically master the content, and adopt a variety of teaching methods to achieve better teaching effect. At present, the main teaching methods are simulation teaching method, cooperative teaching method, project-driven method, case teaching method, combined techniques of multimedia teaching tools and traditional blackboard writing.

\subsubsection{Simulation Teaching Method}

Simulation teaching method is a kind of scene simulation teaching methods. For students majoring in Japanese, it is inevitable that they will find it highly professional and difficult to understand if they want to learn accounting knowledge before having the course. Simulation teaching method can well solve the concerns of interdisciplinary students. In the first class, the students are divided into groups to set up the financial department, purchasing department, sales department and other departments. Then the teacher guides the students to learn the account book and records through the accounting treatment in various transactions, complete the learning of knowledge points, and finally complete the financial statements and analyze the profit and loss of the proposed company. Through this method, students can grasp the stage and function of each account book from a macro perspective, and get practical experience.

\subsubsection{Cooperative Teaching Method}

Through the cooperation within the group, the cooperative teaching method is mainly used to complete the project results, and cultivate students' teamwork awareness and team coordination and communication skills. The course is guided by project. From the first class, the students are required to form a team, carry out effective division of labor and discuss and learn together to complete the final project results.

\subsubsection{Project-driven Method}

Project-driven method is a new teaching method based on constructivism learning theory. The teaching method takes the design and implementation of the project as the main line and students as the main body of teaching. Teachers play the role of guidance, integrate the teaching contents into all aspects of the project implementation, and students complete the learning of each knowledge point with the progress of the project. It is a typical student-centered teaching method, which is of great significance to give full play to students' interest in learning and improve their autonomous learning ability and innovation ability.

\subsubsection{Case Teaching Method}

Case teaching method is used to arouse students' thinking and exploration through specific cases, and then, students can actively complete the teaching contents. In the process of completing the project, each specific transaction of the company will be taken as a case to introduce knowledge points. Students complete the learning of each knowledge point by solving each case, and the boring knowledge points will be more specific, more practical and easy to be understood. For beginners of Japanese bookkeeping, teachers should pay attention to the case selection and the fit with the teaching contents, and extract the relevant contents from the comprehensive case to construct the case. 
For example, when talking about the recording method of account book of goods in stock, teachers can select the purchase, sales and inventory cases of apple in the fruit store to introduce, analyze and record the account book.

\subsubsection{Combined Techniques of Multimedia Courseware and Traditional Blackboard Writing}

For students majoring in Japanese who have no practical accounting work experience, the daily use of accounting vouchers, account books, financial statements and other things in the accounting industry are very abstract for them. The actual vouchers, account books and other things can be displayed to students through multimedia teaching tools in the form of pictures, so that students can have an intuitive understanding. When drawing tables, teachers can use multimedia teaching tools to display media courseware step by step, so as to avoid the irregularity of the freehand sketching on the blackboard and save time. However, in the specific use of formula for calculation and other knowledge, the teacher's practical step-by-step demonstration on the blackboard is more convenient for students to learn the calculation process and ideas. Therefore, according to the characteristics of the knowledge taught, multimedia courseware and traditional blackboard writing are combined to achieve the optimal use of resources.

\subsection{Teaching Implementation}

In the actual teaching process, the learning objects, the characteristics of the teaching content of each chapter and the focus of teaching are different. It is necessary to reasonably select and comprehensively use various teaching methods. In the following, it introduces the practical application of various teaching methods in Japanese bookkeeping course.

\subsubsection{Project Guidance}

In order to facilitate interdisciplinary students' overall understanding of the course, the project "Corporation Inc" is designed throughout the whole course. Students are required to plan and complete business bookkeeping between two companies in groups, and make financial statements to reflect the financial process of daily bookkeeping and annual bookkeeping. The task of the proposed company by groups should be carried out in the first class, and the specific project requirements should be given to the students, so that the students can have a general understanding of the Japanese bookkeeping course. At the same time, it is necessary to be clear that the teaching content of each unit is to prepare for the completion of this project.

\subsubsection{Project Design}

According to the requirements, every six students will be divided into a group in the first class. Each group plans to build two business companies, and designs the name, business scope, assets, number of employees, etc. of each company. According to the needs, it is to build the proposed departments, including the finance department, purchasing department, sales department. Through the transaction of each department, the accountant of finance department will keep accounts. In the specific implementation process of the project, each student works as an accountant of the financial department. Through the study of each knowledge point, students can improve their own business ability to complete the final project results.

\subsubsection{Project Implementation}

The learning of each knowledge point is the specific process of project implementation.

- Case analysis

Taking the learning of knowledge points of recording commodity in warehouse as an example, the case is introduced. The purchase, sale and inventory information of apples in a fruit store within one month is as follows:

May 1st, carried over from the previous month $5 @ 50$

May 7th, purchased $15 @ 60$

May 19th, sold $10 @ 90$ (selling price)

May 22nd, purchased $10 @ 55$

May 28th, sold $14 @ 95$ (selling price)

At the same time, it is required to put forward some questions to the students, for example, as a store, how to record the account book of goods in stock? What should we do with the apples left over from last month? Is the purchase price or the sale price to be used for the bookkeeping of the purchase and sale? If the purchase price is used for bookkeeping, there are two kinds of situations. Which purchase price is used for bookkeeping when selling?

- Bookkeeping and record 
After the first step of analysis and thinking, the formula needed to master to record the commodity account book is derived, so that students can understand the role of recording the commodity account book in the company's financial management and make the record on the account book. When explaining the formula, the teacher uses the form of blackboard writing to explain the calculation on the blackboard, which is convenient for the students to clear the thinking of calculation. in the process of specific bookkeeping, the multimedia courseware is used to show each recording step. Students can master knowledge points and learn to take bookkeeping by analysing and learning.

\section{- Writing corresponding business records}

Through the specific learning of each knowledge point, each group combined with the business content of the two proposed business companies, compiled the corresponding business records and completed the corresponding accounting entries.

\section{- $\quad$ Final accounting}

Due to the characteristics of bookkeeping course, it is necessary to sort out and analyze the final accounts of the whole accounting year, integrate the trial balance sheet and actuarial table, and complete the financial statements at the end of an accounting year.

- $\quad$ Submitting results

It is required to complete the following documents at the end of the course through the study of each unit: 30 business transaction records and corresponding accounting entries of each proposed two companies (reflecting at least 15 accounting accounts), one trial balance sheet, one actuarial statement, one simple financial statement (balance sheet, income statement).

\subsubsection{Project Evaluation}

For the project results submitted by students, teachers can organize students to conduct mutual evaluation among groups, and finally teachers can make a summary evaluation on the overall situation. Due to the characteristics of the design of the project achievements and the course content, the mutual evaluation of the project among groups is more complex. Taking Group A and Group B as examples, Group A and Group B carry out the following five steps at the same time. In the following, it mainly takes the project achievements submitted by Group A as an example. For the evaluation of the project achievements of Group B, Group A and Group B can make the exchange.

- First of all, Group A only handed over the two business transaction records prepared by this group to Group B;

- Students of Group B completed the corresponding accounting entries according to the business transaction records compiled by Group A and submit them to Group A;

- For the first inter-group evaluation, the evaluation content of group $\mathrm{A}$ is on whether the accounting entries submitted by Group B are correct, and the evaluation content of Group B is on whether the business transaction records compiled by Group A are reasonable;

- Group A will hand over all the project achievements submitted by this group to Group B;

- For the second inter-group evaluation, students in Group B evaluated whether the corresponding accounting entries, trial balance, actuarial statements and simple financial statements were reasonable and accurate according to the business transaction records compiled by Group A.

After the mutual evaluation, the opinions and results of the mutual evaluation will be submitted to the teachers for final confirmation and evaluation. And the most reasonable results will be used as case analysis.

In the above project-oriented teaching process, simulation teaching method, cooperative teaching method, project-driven method, case teaching method, combined techniques of multimedia teaching tools and traditional blackboard writing are comprehensively used. Students can intuitively and vividly understand the content of "Japanese bookkeeping" course, master the basic process of Japanese bookkeeping, master how to keep accounts and fill in account books when enterprises trade commodities, and learn the methods of daily bookkeeping and annual bookkeeping. With the study in one semester, some students took part in the level 3 proficiency test of bookkeeping, passed the test with higher scores and obtained the level 3 qualification certificate of bookkeeping.

\section{CONCLUSION}

As an interdisciplinary course for Japanese majors, "Japanese bookkeeping" will benefit the 
students most directly. After completing this course, students can participate in the level 3 qualification examination of bookkeeping. It not only increases the competitive weight in employment, but also provides new job-hunting fields and industrial choices. In addition, students can constantly improve themselves in the future study and work, and obtain higher-level certification. How to effectively cultivate interdisciplinary Japanese bookkeeping talents needs constant exploration and practice in teaching materials, teaching methods and teachers. Bookkeeping course is a basic subject of curriculum system of Japanese universities, with rich teaching experience. And it can be used for reference in order to perfect the teaching mode construction of Japanese bookkeeping course in China.

\section{AUTHORS' CONTRIBUTIONS}

This paper is independently completed by Yingying Fu.

\section{REFERENCES}

[1] Du Peijuan. The construction and implementation of Japanese bookkeeping courses under the CDIO concept $[\mathrm{J}]$. Journal of Shanxi Institute of Energy, 2016 (8). (in Chinese)

[2] Jin Yan. Optimizing the teaching content and methods of financial accounting courses for non-accounting majors [J]. Journal of Zhejiang Shuren University, 2009(9). (in Chinese)

[3] Masao Mochikawa. Study on the introduction of "bookkeeping" in colleges and universities [J]. Economics Research Collection of Hiroshima University, 2010 (9). (in Chinese)

[4] Yu Xiangyong. Research on Teaching Practice and Teaching Material Development of Japanese Style Bookkeeping in Colleges and Universities [J]. China Economist, 2018(5). (in Chinese)

[5] Zhang Yanyan. Feasibility Analysis of "Japanese Bookkeeping + Foreign Language" Teaching Mode in Colleges and Universities in Henan Province [J]. Journal of Henan Institute of Technology (Social Science Edition), 2019, (03). (in Chinese)
[6] Zhang Liya. The Application of Courseware in English Bookkeeping Teaching [J]. Journal of Education Development, 2001 (1). (in Chinese) 